\title{
RESENSI PUISI DUA KAKI
}

\author{
AYU WULAN SARI \\ Universitas Nahdlatul Ulama Sidoarjo
}
A. IDENTITAS PUISI
Judul puisi
: Dua Kaki
Penulis
: Agung Purnomo
Jenis puisi
: Syair bebas
Bahasa
: Indonesia

\section{B. IDENTITAS BUKU}

\section{Judul buku}

Penyunting/editor

Desainer sampul

Desainer ilustrasi

ISBN

Penerbit

Tahun terbit

Tebal

Sampul

Harga

Lingkup penerbitan

Dimensi
: Kidung Nawala, Jilid 2

: Fatkul Anam, Hadi Ismanto \& Khoifulloh

: Agung Purnomo

: Masudin Fahmi

: 978-602-51116-8-6

: UNUSIDA Press, Sidoarjo

: 2018

: 68 halaman +7 halaman

: Latar merah muda dan tulisan putih

: Rp 50.000 (Tokopedia), Rp.50.000 (Bukalapak)

: Nasional

: $14,5 \times 21 \mathrm{~cm}$ 


\title{
C. RESENSI BUKU DAN PUISI
}

Berikut adalah potongan puisi berjudul dua kaki, yakni:

\author{
Dua kaki ... \\ Malang dan Sidoarjo \\ Diabaikan dan diberdayakan \\ Istikharoh dan ikhtiar \\ Jauh dan dekat \\ Kerja dan ibadah \\ Kenalan dan teman
}

Puisi berjudul dua kaki ini ditulis oleh Agung Purnomo, seorang dosen perguruan tinggi di Malang, Sidoarjo dan Sumenep. Usianya yang masih tergolong muda yakni lahir pada tahun 1981. Penulis lahir dan besar di kota Sidoarjo.

Penulis Agung Purnomo selain menulis puisi bertajuk dua kaki (Purnomo, 2018b), juga menulis syair berjudul sebagai berikut: tangisnya (Purnomo \& Asitah, 2019e), pandai (Purnomo \& Asitah, 2019c), dan kita (Purnomo \& Rosyidah, 2019), rindu di ubunubun (Purnomo, 2019c), sepekan awal tanpamu (Purnomo \& Asitah, 2019d), \#CH1 (Purnomo, 2018a), cantik (Purnomo \& Asitah, 2019b), berpulang (Purnomo, 2019a), bapak Samsuri (Purnomo \& Asitah, 2019a), dan menyala (Purnomo, 2019b). 
Puisi dua kaki ini memaparkan tentang perjalanan hidup sang penulis diantara dua dunia. Kadang diposisikan harus memilih antara dua pilihan. Antara berkarir di Malang atau di Sidoarjo?. Antara menjadi pengusaha atau berkarir sebagai dosen. Puisi ketika dibaca cukup ringan dan enak untuk dibaca. Puisi ini, tampaknya, lebih tepat dan bermanfaat bagi para pelajar, remaja, dan pekerja.

Buku antologi puisi berjudul Kidung Nawala Jilid 2 ini terdiri atas 24 karya puisi dari 24 penulis. Buku antologi puisi ini membebaskan penulis untuk berkarya tanpa tema tertentu. Cover buku dilaminasi dove sehingga tidak mengkilap ketika dilihat dan di foto. Beberapa masukan untuk perbaikan kualitas buku adalah memberikan biodata penulis sehingga pembaca lebih memahami puisinya.

Puisi berjudul dua kaki di dalam buku antologi puisi bertajuk Kidung Nawala jilid 2 sangat berguna, khususnya bagi pelajar, remaja, dan pekerja. Bagaimana menyikapi hidup dengan beragam pilihan. Puisi ketika dibaca cukup ringan dan enak untuk dibaca. Jadi, upaya Agung Purnomo patut diberi apresiasi dan acungan jempol. 


\section{REFERENCES}

Purnomo, A. (2018a). \#CH1. In Kidung Nawala (Jilid 1). Sidoarjo: UNUSIDA Press.

Purnomo, A. (2018b). Dua Kaki. In Kidung Nawala (Jilid 2). Sidoarjo: UNUSIDA Press.

Purnomo, A. (2019a). Berpulang. In Syair Nimala.

Sumenep: STIEBA Madura Press.

Purnomo, A. (2019b). Menyala. In Tenta Kimaya.

Sumenep: STIEBA Madura Press.

Purnomo, A. (2019c). Rindu di Ubun-Ubun. In

Rassana Jlantir. Sumenep: STIEBA Madura

Press.

Purnomo, A., \& Asitah, N. (2019a). Bapak Samsuri.

In Dhalubang Marta. Sumenep: STIEBA

Madura Press.

Purnomo, A., \& Asitah, N. (2019b). Cantik. In

Lembhar Jiwana. Sumenep: STIEBA Madura

Press.

Purnomo, A., \& Asitah, N. (2019c). Pandai. In

Tolesan Aditi. Sumenep: STIEBA Madura Press.

Purnomo, A., \& Asitah, N. (2019d). Sepekan Awal

Tanpamu. In Arebhan Helai. Sumenep: STIEBA

Madura Press.

Purnomo, A., \& Asitah, N. (2019e). Tangisnya. In

Bhumi Bawera. Sumenep: STIEBA Madura

Press.

Purnomo, A., \& Rosyidah, E. (2019). Kita. In Suweda Ate. Sumenep: STIEBA Madura Press. 